\title{
PENGEMBANGAN APLIKASI WEB KOST-KOSTAN DI KOTA BATAM DENGAN METODE EXTREME PROGRAMMING
}

\author{
${ }^{1)}$ Daniel Apdianto Herman, ${ }^{2)}$ Michael \\ ${ }^{1,2}$ Sistem Informasi, Ilmu Komputer, Universitas Internasional Batam \\ ${ }^{1,2}$ Baloi Mas Indah Block A Nomor $12 b$ - Kepulauan Riau - Indonesia \\ E-mail : ${ }^{1)}$ Daniel.herman@uib.ac.id, ${ }^{2)}$ 1831143.michael@uib.edu
}

\begin{abstract}
ABSTRAK
Setiap tahunnya, terdapat banyak mahasiswa baru dari luar kota datang untuk melanjutkan jenjang pendidikannya di tempat baru. Secara tidak langsung kebutuhan akan tempat tinggal akan meningkat secara proposional, terutama di daerah yang dekat dengan institusi pendidikan tinggi. Tapi sering kali keterbatasan informasi membuat para calon mahasiswa maupun mahasiswa baru mengalami kebingungan dalam mencari informasi tempat tinggal atau kost. Oleh karena itu, penulis berniat mengembangkan sebuah aplikasi web kost-kostan yang dimana dapat menyediakan informasi tersebut dan menghubungkan penyedia kost dengan pencari kost. Aplikasi web juga sangat fleksibel sehingga dapat diakses kapan saja dan dari mana saja asal terhubung dengan internet. Selama proses penelitan ini penulis menerapkan metode Extreme Programming (XP). Penelitian nantinya akan menghasilkan sebuah aplikasi web dimana penyedia kost dapat mempromosikan kost-kostannya dan juga pencari kost dapat mencari kost yang diinginkan dengan segala informasi sudah tertera didalam aplikasi. Dari penelitian ini penulis menyimpulkan aplikasi web kost-kostan sangat dibutuhkan pada saat ini. Penerapan XP sebagai metode penelitian juga sangat cocok dikarenakan jangka waktu yang cukup singkat dan tentunya metode XP sangat terstruktur selama penerapannya.
\end{abstract}

Kata Kunci: kos, aplikasi web, extreme programming.

\begin{abstract}
On yearly basis, many new students coming from outside the city who plan to continue their education in a new environment or place. Because of this, the need for housing also increases proportionally, especially in the areas that are close to university institutions. But often due to the limited information confused the prospective and new coming students in finding the housing to live on. Therefore, the author intends to develop a boarding house web application that can provide this information and connect the boarding house provider with the boarding house seeker. This is also very flexible as it can be accessed anytime and anywhere as long as it has an internet connection. The author applies the Extreme Programming (XP) methodology during this research process. At the end of the research, a boarding house web application will be produced where the boarding house owner can promote their housing and the boarding house seeker can find the desired housing with all the information listed inside the application. From this research, the author concludes that the boarding house application is needed at this time. And the application of XP methodology is very suitable because of the short period of research and of course because the XP methodology is very structured.
\end{abstract}

Keyword: boarding house, web application, extreme programming.

\section{PENDAHULUAN}

Setiap tahunnya terdapat banyak lulusan sekolah yang akan melanjutkan jenjang pendidikannya ke tingkat perkuliahan. Baik dari kota itu sendiri maupun dari kota-kota lain yang merantau ke suatu kota demi melanjutkan ke jenjang kuliah. Secara tidak langsung kebutuhan akan tempat tinggal akan meningkat secara proposional, terutama di daerah tempat sebuah institusi pendidikan tinggi yang memiliki reputasi baik.Jenjang perkuliahan sendiri juga dibilang tidak begitu panjang, dimana rata-rata dapat diselesaikan dalam waktu kurang lebih 4 tahun. Karena itu banyak calon-calon mahasiswa ataupun mahasiswa itu sendiri mencari tempat tinggal yang sifatnya sementara atau lebih dikenal dengan istilah kost.

Namun dengan ketersediaan informasi yang cukup terbatas, para calon mahasiswa maupun mahasiswa baru itu sendiri cenderung tidak memiliki informasi yang akurat maupun relavan mengenai lokasi kost. Hal itu juga yang menyebabkan kurangnya informasi mengenai biaya sewa maupun lokasi kost secara tepat. Kondisi ini sering terjadi, tidak terkecuali untuk para calon mahasiswa maupun mahasiswa baru 
di Batam. Penulis sendiri juga merasakan hal yang sama waktu pertama kali datang ke kota Batam untuk melanjutkan kuliah. Mau tidak mau karena minimnya informasi, penulis harus mendatangi suatu lokasi dan jalan mengelilingi sekitar untuk mencari tempat kost.

Kondisi seperti ini tentunya membutuhkan sebuah sistem informasi yang dapat memudahkan dalam mencari maupun menentukan pilihan kost. Aplikasi Web sendiri merupakan salah satu sistem informasi yang dimana sering dan banyak akses oleh masyarakat untuk mendapat informasi saat berinternet. Aplikasi web banyak di pakai karena minimnya biaya instalasi, peningkatan fitur secara otomatis, dan akses secara universal dari semua perangkat yang terhubung ke internet [1]. Para pengguna bisa mengakses aplikasi web dari browser yang ada di komputer, di gawai elektronik, dimana saja, kapan saja dengan syarat terhubung koneksi internet.

Jika dengan adanya sebuah aplikasi web kost-kostan, maka akan sangat berguna sebagai salah satu penyedia informasi yang akurat dan lengkap mengenai tempat kost, harga sewa, maupun rupa kost. Calon mahasiswa maupun mahasiswa baru tidak perlu menghabiskan waktu untuk mendatangi suatu wilayah dan mencari satu demi satu guna mendapat informasi mengenai suatu tempat kost. Hanya dengan mengujungi aplikasi web, maka semua informasi tersebut akan langsung didapat, waktu yang terpakai juga sangat minimal. Ketersediaan informasi mengenai hal-hal lainnya seperti fasilitas, ketersedian kamar, hingga lokasi peta juga bisa didapat melalui aplikasi web.

Tentunya untuk pengembangan aplikasi web itu sendiri terdapat banyak hal yang harus diperhatikan. Maka diperlukannya metode yang dapat membantu dalam proses pengembangan aplikasi web. Extreme Programming (XP) merupakan metode yang dikenal sangat membantu dalam pengembangan aplikasi web berkualitas tinggi dan project berskala kecil dan sedang [2]. XP sendiri terdiri dari 4 tahap yang harus dilalui dalam penerapannya, yaitu Planning, Design, Coding, Testing [3]. Ke- empat tahap tersebut bakal dilalui terus menerus selama proses pengembangan sehingga akan menghasilkan sebuah aplikasi web yang berkualitas tinggi.

\section{Website}

Website ialah kumpulan informasi informasi dalam bentuk halaman ataupun kumpulan halaman yang berisi informasi tertentu yang saling terhubung dan bisa diakses oleh semua orang dengan menggunakan browser. Website juga menjadi media bagi masyarakat untuk lebih mudah mendapatkan informasi [4]. Dikarenakan kemudahan dalam mengaksesnya serta dapat diakses dari mana saja, kapan saja dan tanpa terbatas oleh wilayah geogratis, website menjadi sangat populer di era modern sekarang.

\section{Kost}

Kost atau biasa dikenal dengan sebutkan indekos merupakan tempat tinggal sementara untuk jangka waktu yang tidak terlalu panjang. Kost-kost an menjadi hunian favorit bagi banyak perantau karena harga sewa yang lebih murah (dengan fasiltias minim), lokasi yang tersebar luas sehingga para perantau bisa memilih lokasi yang diinginkan serta akses dan kebebasan yang tinggi [5].

\section{Agile Methodology}

Merupakan pengembangan software yang dilakukan secara bertahap dan berulang. Dalam menjalan metode agile ini, perlu dilakukan secara terorganisir, terstruktur dan kolaboratif bagi setiap pihak yang bekerja sama. Bukan hanya ini, agile juga menuntut kecepatan dalam proses pengambilan keputusan selama proses penerapannya. Menurut [6] dalam penelitiannya, ada beberapa alasan kenapa agile lebih banyak diterima dan digunakan seperti:

- Dalam penerapannya, pengguna merupakan prioritas utamanya sehingga pengguna Scmerasa puas dan juga keberlangsungan pengembangan pada aplikasi dapat terjamin.

- Agile telah didesign untuk menerima setiap perubahan selama proses pengembangan atau penerapannya. 
- Agile membantu dalam menghasilkan aplikasi jadi atau siap pakai dalam jangka waktu yang pendek.

- Setiap tim dalam perusahaan bekerjasama dan saling berhubungan selama proses pengembahangan sehingga persentase produk atau aplikasi ditolak dan waktu yang dibutuhkan menurun.

Sebagai sebuah framework, agile menggunakan beberapa metode yang berbeda seperti SCRUM, Scaled Agile Framework (SAFe), Lean Software Development (LSD), Extreme Programming (XP), Dynamic Systems Development Method (DSDM) dan Feature Driven Development (FDD). Dalam penelitian yang dilakukan oleh [7] disebutkan bahwa 65\% dari perusahaan beskala sedang menginformasikan bahwa $100 \%$ tim didalam perusahaan menggunakan agile dalam pengembangan software. Diantara metode agile yang ada, Extreme Programming (XP) merupakan salah satu metode yang cukup sering digunakan dalam mengembangkan dan meningkatkan software e-coommerce [8].

\section{Extreme Programming (XP)}

Extreme Programming atau XP merupakan metodologi perangkat lunak yang ringan dimana digunakan untuk pengembangan aplikasi dalam menghadapi persyaratan yang belum jelas ataupun yang sering berubah selama masa pengembangan perangkat lunak [6]. XP sering kali di terapkan dalan kelompok atau tim pengembang dengan jumlah pengembang yang berskala kecil ke sedang yang dalam angka berkisar antara 3-10 orang. XP memiliki 5 nilai dasar, antara lain Simplicity, Courage, Communication, Respect dan Feedback [9].

\section{METODE}

Guna mencapai tujuan penelitian yaitu aplikasi kost-kostan yang dapat membantu para pengguna dalam mencari maupun mempromosikan kost, penulis membagi proses penelitian menjadi beberapa tahap sesuai dengan metode Extreme Programming.

\section{Kerangka Kerja Penelitian}

Kerangka Penelitian dengan judul "Pengembangan Aplikasi Web Kost-kosan di Kota Batam Dengan Metode Extreme Programming" ditujukan pada Gambar 1

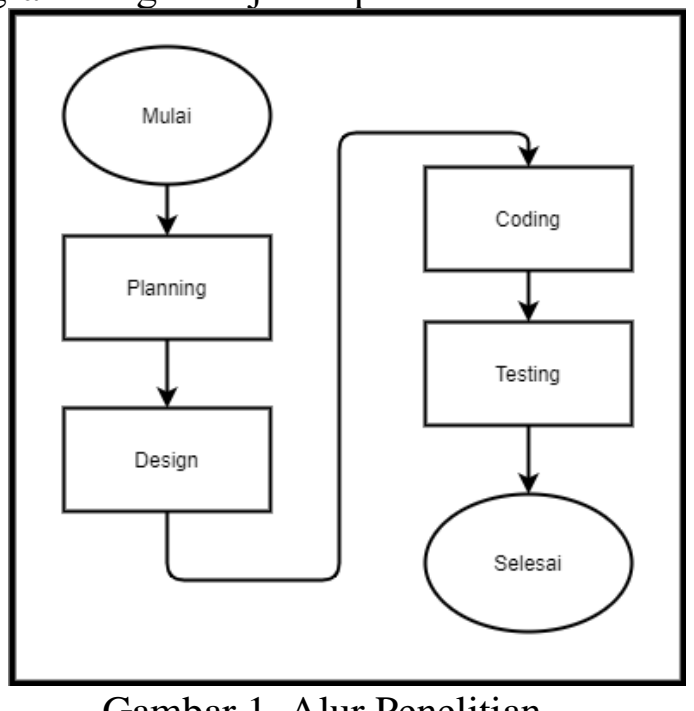

Gambar 1. Alur Penelitian

\section{Planning}

Tahap Planning ini bertujuan untuk dilakukannya analisa terhadap latar belakang masalah yang sudah tentukan sebelumnya. Penulis juga harus mengumpulkan segala kebutuhan yang diperlukan selama masa pembuatan aplikasi web. Maka ditahap ini akan dihasilkannya Identifikasi Masalah dan Analisa Kebutuhan yang dimana Analisa Kebutuhan akan di bagi menjadi 2 yaitu Kebutuhan Fungsional dan Non-fungsional.

\section{Design}

Design atau biasa lebih dikenal dengan tahap perancangan. Penulis pada tahap ini akan mulai untuk menentukan Pemodelan sistem yang berupa Use Case Diagram. Dengan ditentukannya pemodelan sistem, maka akan lebih jelas apa saja proses yang akan terjadi dan apa saja akses yang diperlukan oleh pengguna. Selanjutnya setelah pemodelan sistem akan dilanjutkan dengan Pemodelan Basis Data. Dari pemodelan basis data akan dihasilkan ERD sebagai gambaran bagaimana struktur dari database yang akan dibuat. 


\section{Coding}

Setelah analisa dan perancangan telah siap dilakukan, maka penulis akan mulai melakukan Coding untuk menghasilkan sebuah aplikasi yang sesuai dengan perancangan sebelumnnya. Tahap ini lebih dikenal dengan namanya Pengembangan Aplikasi. Semua kebutuhan dan fungsi akan dikembangkan selama tahap ini berlangsung.

\section{Testing}

Setelah pengembangan aplikasi telah selesai dibuat maka penulis akan melanjutkannya ke tahap Testing yaitu tahap terakhir dari metode XP. Penulisakan menggunakan metode BlackBox Testing yang dimana dalam masa pengujian akan berfokus pada detail aplikasi seperti contohnya tampilan aplikasi, fungsifungsi, dan fitur aplikasi yang terdapat didalam aplikasi dan kesesuaian proses atau alur yang dirancang sebelumnya. Pengujian dengan metode ini juga sangat bagus karena akan didasarkan pada sudut pandang pengguna sehingga akan didapatkan hasil apakah aplikasi yang dikembangkan sudah sesuai atau belum.

\section{HASIL}

\section{Analisa Kebtuhan}

Berdasarkan analisa yang berhasil dilakukan penulis, berhasil disimpulkan analisa fungsional dan non-fungsional sebagai berikut.

\begin{tabular}{ll}
\hline No & Kebutuhan Fungsional \\
\hline $\mathbf{1}$ & $\begin{array}{l}\text { Sistem dapat melakukan } \\
\text { penambahkan pengguna baru }\end{array}$ \\
\hline $\mathbf{2}$ & $\begin{array}{l}\text { Sistem dapat menampilkan menu } \\
\text { login dan logout }\end{array}$ \\
\hline $\mathbf{3}$ & $\begin{array}{l}\text { Sistem dapat menampilkan seluruh } \\
\text { data kost yang telah dibuat }\end{array}$ \\
\hline $\mathbf{4}$ & $\begin{array}{l}\text { Sistem dapat melakukan CRUD } \\
\text { untuk kost }\end{array}$ \\
\hline $\mathbf{5}$ & $\begin{array}{l}\text { Sistem dapat menyimpan data } \\
\text { pengguna yang tertarik dengan kost } \\
\text { yang tersedia didalam aplikasi }\end{array}$ \\
\hline & Tabel 1. Kebutuhan Fungsional
\end{tabular}

\begin{tabular}{ll}
\hline No & Kebutuhan Non-fungsional \\
\hline $\mathbf{1}$ & Sistem mempunyai tampilan yang \\
\hline
\end{tabular}

\begin{tabular}{ll}
\hline & simple dan mudah dipahami \\
\hline $\mathbf{2}$ & $\begin{array}{l}\text { Sistem dapat dioperasikan dan } \\
\text { menampilkan data dengan benar }\end{array}$ \\
\hline $\mathbf{3}$ & $\begin{array}{l}\text { Sistem dapat dioperasikan sesuai } \\
\text { fungsinya }\end{array}$ \\
\hline $\mathbf{4}$ & $\begin{array}{l}\text { Sistem dapat diakses dengan } \\
\text { perangkat PC atau smartphone }\end{array}$ \\
\hline $\mathbf{5}$ & $\begin{array}{l}\text { Sistem dapat menjamin keamanan } \\
\text { data }\end{array}$ \\
\hline & Tabel 2. Kebutuhan Non-fungsional
\end{tabular}

\section{Use Case Diagram}

Perancangan Use Case Diagram yang berhasil dibuat oleh penulis untuk penelitian ini ditunjukan oleh Gambar 2.

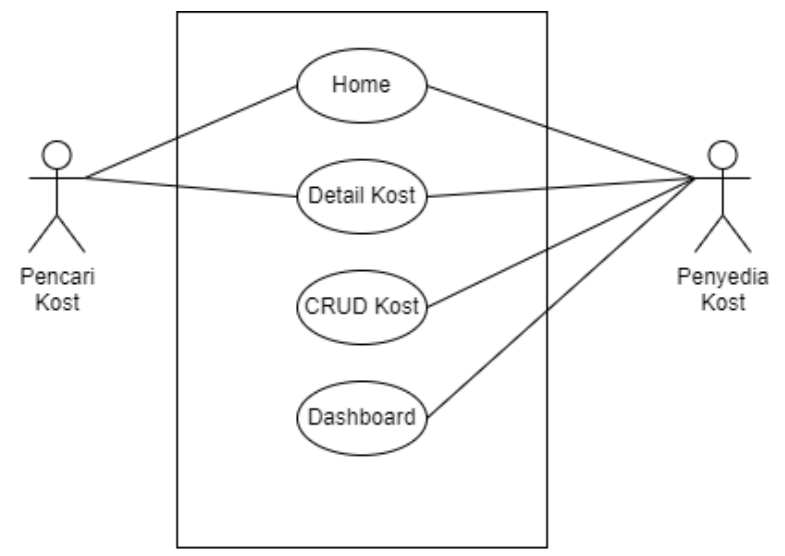

Gambar 2. Use Case Diagram

\section{Entity Relationship Diagram (ERD)}

Perancangan selanjutnya oleh penulis adalah ERD, dimana tabel dan relasinya yang akan dikembangkan selama penelitian ini.

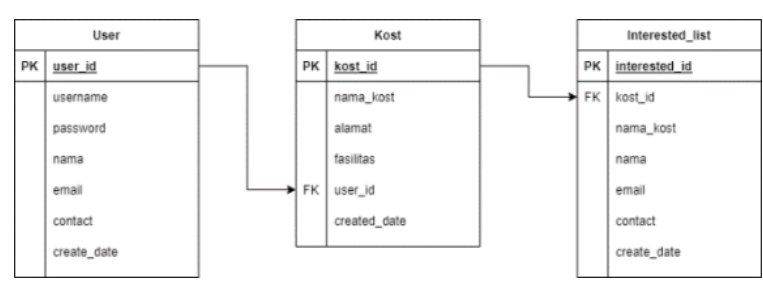

Gambar 3. Entity Relationship Diagram

\section{Implementasi}

Implementasi merupakan salah satu langkah dari perancangan dan pengembangan sebuah aplikasi. Implementasi yang dilakukan nantinya mencakup frontend dan backend. Setelah proses implementasi berhasil, aplikasi akan bisa di akses oleh para pengguna dan tentunya 
sudah lewat testing.

\section{Halaman Utama}

Merupakan halaman yang muncul ketika pertama kali pengguna mengunjungi aplikasi. Terdapat 2 navigasi berupa home page dan login page.
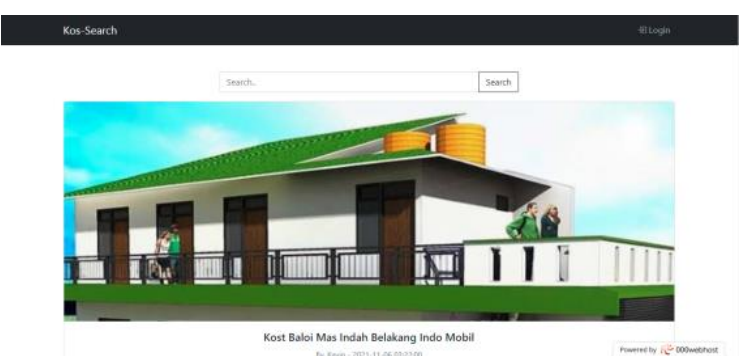

Gambar 4. Halaman Utama

\section{Halaman Login}

Pada halaman ini penyedia kost harus memasukan username dan password untuk dapat mengakses dashboard. Pada halaman ini juga terdapat navigasi untuk mendaftar bagi para penyedia kost baru.

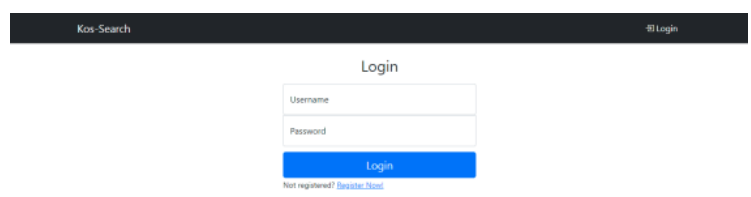

Gambar 5. Halaman Login

\section{Halaman Register}

Halaman dimana para penyedia kost yang masih baru dengan aplikasi bisa mendaftarkan akun, setelah didaftarkan penyedia kost dapat melanjutkan promosi kost-kost miliknya didalam aplikasi.

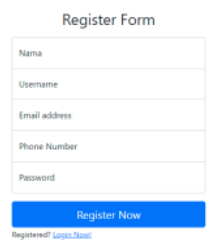

Gambar 6. Halaman Register

\section{Halaman Dashboard}

Halaman yang muncul pertama kali setelah pengguna atau penyedia kost setelah berhasil login. Halaman ini menunjukan setiap nama dan contact dari para pencari kost yang sudah berhasil melakukan input data setelah tertarik dengan kost yang dilihatnya. Penyedia kost dapat langsung menghubungi para pencari kost tersebut.

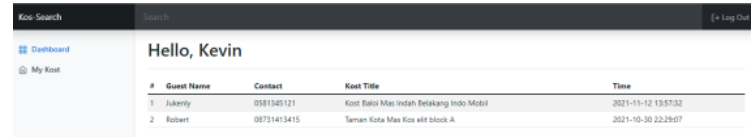

Gambar 7. Halaman Dashboard

\section{Halaman My Kost}

Halaman yang menunjukan seluruh kost yang telah pernah dibuat oleh penyedia kost untuk di promosikan didalam aplikasi. Penyedia kost dapat melakukan CRUD dihalaman ini.

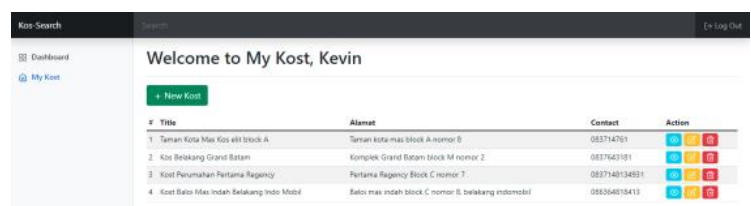

Gambar 8. Halaman My Kost

\section{Halaman Detail Kost}

Merupakan halaman yang menunjukan informasi lebih detail tentang kost yang dilihat. Informasi yang tertera berupa fasilitas, alamat, informasi tambahan dari penyedia kost serta terdapat tombol untuk menunjukan bahwa kamu tertarik akan kost yang sedang dilihat. 


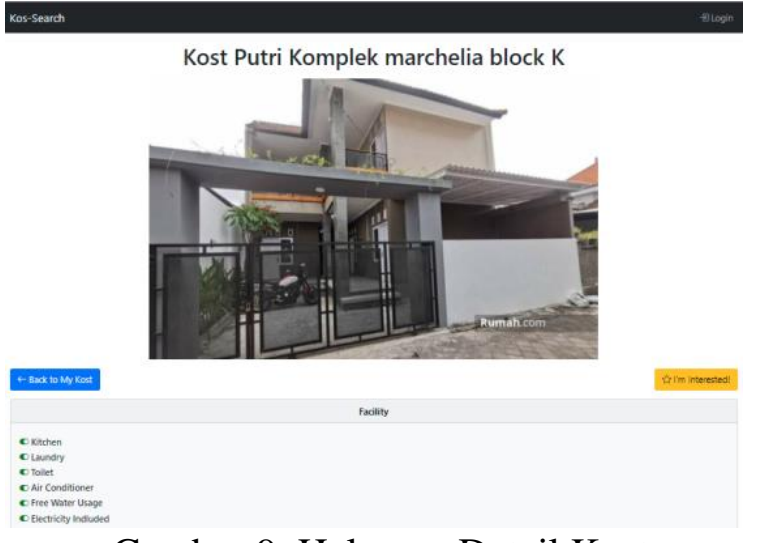

Gambar 9. Halaman Detail Kost

\section{Halaman Modal}

Modal baru akan muncul setelah menekan tombol "I'm Interested" yang dimana pengguna atau para pencari kost dapat mengikan informasi seperti nama, email dan nomor $\mathrm{hp}$ yang bisa di hubungi, yang dimana nantinya informasi ini akan diterima oleh penyedia kost dan penyedia kost dapat menghubungi pencari kost.

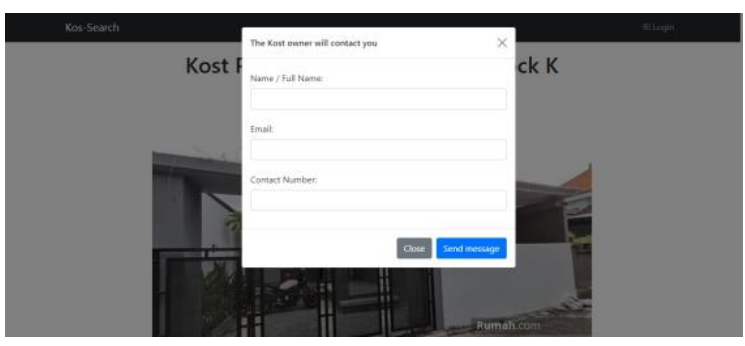

Gambar 10. Halaman Modal

\section{Pengujian Blackbox}

Berdasarkan analisa fungsional maka akan dilakukan pengujian fungsional blackbox yang bertujuan untuk memastikan segala kebutuhan sistem yang telah dibuat bekerja dan berjalan dengan baik.

\begin{tabular}{ll}
\hline \multicolumn{1}{c}{ Blackbox } & Status \\
\hline Kebutuhan Fungsional & Passed \\
\hline $\begin{array}{l}\text { Sistem dapat melakukan } \\
\text { penambahkan pengguna baru }\end{array}$ & \\
\hline $\begin{array}{l}\text { Sistem dapat menampilkan menu } \\
\text { login dan logout }\end{array}$ & Passed \\
\hline $\begin{array}{l}\text { Sistem dapat menampilkan } \\
\text { seluruh data kost yang telah } \\
\text { dibuat }\end{array}$ & Passed \\
\hline Sistem dapat melakukan CRUD & Passed \\
\hline
\end{tabular}

Sistem dapat menyimpan data

Passed

pengguna yang tertarik dengan

kost yang tersedia didalam

aplikasi

Tabel 3. Blackbox Testing

\section{KESIMPULAN}

Dari penelitian yang telah penulis berhasil lakukan, didapatkan kesimpulan bahwa aplikasi kost-kostan merupakan aplikasi yang dibutuhkan pada saat ini. Aplikasi bukan hanya berfokus pada memudahkan pengguna dalam mendapatkan informasi mengenai kost yang tersedia, tapi juga menjadi sebuah media atau tempat bagi para penyedia kost untuk mempromosikan kost-kostannya. Dulunya informasi kost-kostan hanya dapat didapatkan dari mulut ke mulut maupun hanya dengan datang ke lokasi. Tetapi dengan adanya aplikasi web maka informasi akan kost dapat didapatkan dengan cepat dan efisien.

\section{DAFTAR PUSTAKA}

[1] D. W. L. Pamungkas and S. Rochimah, "Pengujian Aplikasi Web," J. IPTEK, vol. 23, no. 1, pp. 17-24, 2019.

[2] F. Anwer, S. Aftab, and I. Ali, "Proposal of Tailored Extreme Programming Model for Small Projects," Int. J. Comput. Appl., vol. 171, no. 7, pp. 23-27, 2017.

[3] T. Z. Ivgantius and J. F. Andry, "Development of Warehouse Management System Using Extreme Programming," Int. J. Eng. Inf. Syst., vol. 3, no. 9, pp. 39-46, 2019.

[4] M. S. Pinontoan, A. Rachmat, and R. Delima, "Penerapan Metode Waterfall Dan Webqual 4.0 Pada Pengembangan Website Dealer Asa Mandiri Motor," J. Tek. Inform. dan Sist. Inf., vol. 5, no. 2, pp. 201-211, 2019, doi: 10.28932/jutisi.v5i2.1729.

[5] F. Ardiansyah, "SISTEM PREDIKSI HARGA SEWA KOST DENGAN MENGGUNAKAN RANDOM FOREST ANALYTICS ( Studi Kasus: Kost Eksklusif di Daerah Istimewa Yogyakarta ) TUGAS AKHIR," Tugas Akhir, 2020.

[6] A. Singh, "Integrating the Extreme Programing Model with Secure Process for Requirement Selection," Integr. Extrem. PROGRAMING Model WITH Secur. Process Requir. Sel., pp. 423-426, 2018.

[7] A. S. Abdelghany, N. R. Darwish, and H. A. 
Hefni, "An Agile Methodology for Ontology Development," Int. J. Intell. Eng. Syst., vol. 12, no. 2, pp. 170-181, 2019.

[8] M. Adnan, M. Afzal, and K. H. Asif, “OntologyOriented Software Effort Estimation System for E-commerce Applications Based on Extreme Programming and Scrum Methodologies," Comput. J., 2019.

[9] Mukrodin, "Dext-Based Billing Information Systems menggunakan Metode Extreme Programing," J. Sist. Inf. dan Teknol. Perad., vol. 2, no. 1, pp. 6-12, 2021, [Online]. Available: www.journal.peradaban.ac.id. 